\title{
LANDASAN ONTOLOGIS FILSAFAT PANCASILA
}

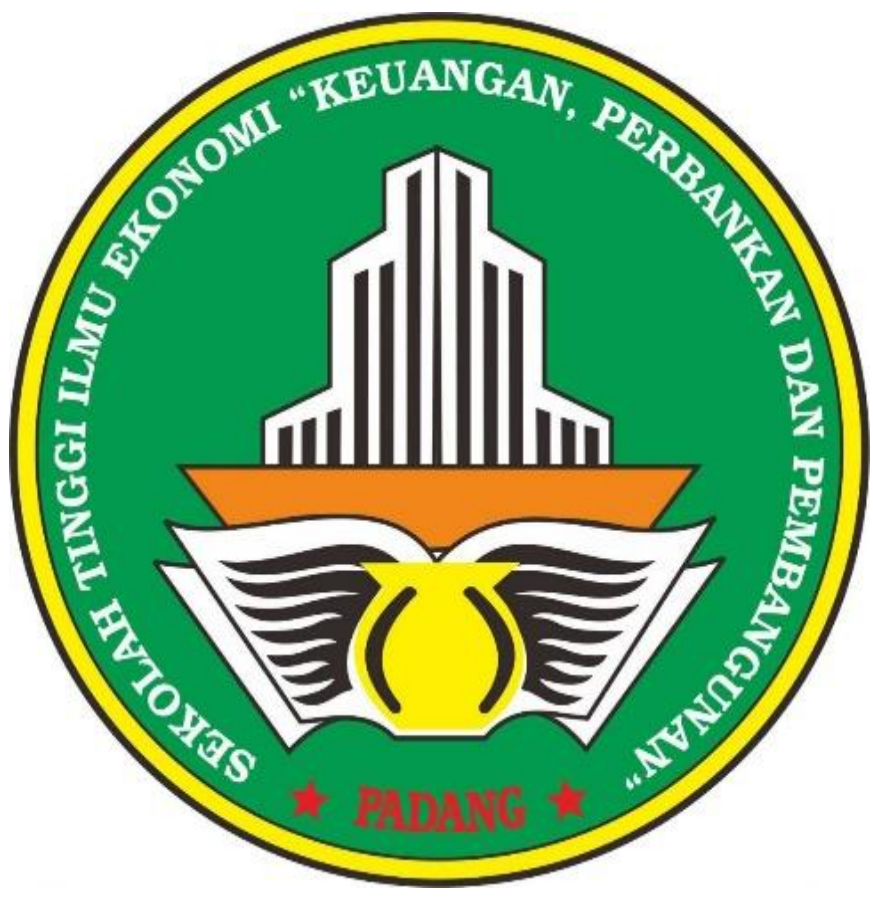

NAMA : MUTIARA SINTA

NIM $\quad: 20220066$

EMAIL : sintamutiara711@gmail.com

SEKOLAH TINGGI ILMU EKONOMI "KEUANGAN,PERBANKAN DAN PEMBANGUNAN" PADANG 


\section{A. PENDAHULUAN}

Perkembangan masyarakat dunia yang semakin cepat secara langsung ataupun tidak langsung mengakibatkan perubahan besar pada berbagai bangsa di dunia. Gelombang besar kekuatan internasional dan transnasional melalui globalisasi telah mengancam, bahkan mengasai eksistensi Negara-negara kebangsaan, termasuk Indonesia. Akibat yang langsung terlihat adalah terjadinya pergeseran nilai-nilai dalam kehidupan kebangsaan karena adanya perbenturan.

kepentingan antara nasionalisme dan internasionalisme. kepentingan antara nasionalisme dan internasionalisme. Permasalahan kebangsaan dan kenegaraan di Indonesia menjadi semakin kompleks dan rumit manakala ancaman internasional yang terjadi di satu sisi, pada sisi yang lain muncul masalah internal, yaitu maraknya tuntutan rakyat, yang secara objektif mengalami suatu kehidupan yang jauh dari kesejahteraan dan keadilan sosial. Paradoks antara kekuasaan global dengan kekuasaan nasional ditambah konflik internal seperti gambaran di atas, mengakibatkan suatu tarik menarik kepentingan yang secara langsung mengancam jati diri bangsa. Nilai-nilai baru yang masuk, baik secara sujektif maupun objektif, serta terjadinya pergeseran nilai di tengah masyarakat yang pada akhirnya mengancamprinsip-prinsip hidup berbangsa masyarakat Indonesia. Prinsip dasar yang telah ditemukan oleh peletak dasar. 
The founding fathers Negara Indonesia yang kemudian diabstraksikan menjadi suatu prinsip dasar filsafat bernegara, itulah pancasila. Dengan pemahaman demikian, maka pancasila sebagai filsafat hidup bangsa Indonesia saat ini mengalami ancaman dengan munculnya nilai nilai baru dari luar dan pergeseran nilai-nilai yang terjadi Secara ilmiah harus disadari bahwa suatu masyarakat suatu bangsa, senantiasa memiliki suatu pandangan hidup atau filsaat hidup masing-masing, yang berbeda dengan bangsa lain didunia. Inilah yang disebut sebagai local genius (kecerdasan/kreatifitas lokal) dan sekaligus sebagai local wisdom (kearifan local) bangsa. Dengan demikian, bangsa Indonesia tidak mungkin memiliki kesamaan pandangan hidup dan filsafat hidup dengan bangsa lain.

\section{B. PEMBAHASAN}

\section{PENGERTIAN LANDASAN ONTOLOGIS FILSAFAT PANCASILA}

a. Pengertian Ontologis

Istilah "Ontologi” berasal dari kata Yunnani onto yang berarti "sesuatu yang sungguh-sunggung ada", kenyataan yang sesungguhnya, dan logos yang berarti "studi tentang ", teori yang membicarakan.

Secara ontologis pancasila sebagai filsafat dimaksudkan sebagai upaya untuk mengetahui hakikat dasar dari sils-sila pancasila. Pancasila terdiri atas lima asas yang berdiri sendiri-sendiri. Manusia merupakan pendukung pokok dari sila-sila pancasila. Maksudnya pada hakikatnya manusia memiliki hakikat mutlak yaitu monopluralis, atau monodulasi sebagai berikut.

> Negara sebagai pendukung hubungan, sedangkan Tuhan, Manusia, satu, rakyat, dan adil sebagai pokok pangkal hubungan. 
Landasan sila-sila pancasila yaitu tuhan, manusia, satu, rakyat dan adil adalah sebagai sebab, dan Negara adalah sebagai akibat.

Ontologi mempelajari ciri hakiki (pokok) dari keberadaan (Being) yang berbeda dari studi tentang hal-hal yang ada secara khusus. Ontologi merupakan cabang filsafat yang membicarakan tatanan (keteraturan) dan struktur kenyataan dalam arti yang luas. Kategori-kategori yang dipakai adalah: meng-ada atau menjadi, aktualltas atau potensionalitas, nyata atau nampak perubahan, eksistensi atau non-eksistensi, hakikat kemutlakan, yang terdalam.

\section{b. Pandangan Ontologis Pancasila}

1. Tuhan adalah sebab pertama (causa prima) dari segalasesuatu, Yang Esa dan segala sesuatu tergantung kepadanya. Tuhan adalah sempurna dan maha kuasa, me-rupakan dzat yang mutlak, ada secara mutlak. Zat yang mulia dan. sempurna. Causa tinalis.

2. Manusia memiliki susunan hakikat. pribadi yang monopluralis. (majemuk tunggal), bertubuh-berjiwa, .berakal-berasaberkehendak, bersifat individu berkedudukan sebagai pribadi berdiri sendiri-makhluk Tuhan yang menimbulkan kebutuhan kejiwaan dan religius, yang seharusnya secara bersama-sama dipelihara dengan baik dalam kesatuan yang seimbang, harmonis dan dinamis.

3. Mengakui adanya kualitas metafisis "satu" (trancendentalone). Iisatu" ialah. secara mutlak tidak dapat terbagi. Merupakan diri pribadi yaitu mempunyai bentuk, susunan, sifat-sifat dankeadaan tersendiri sehingga kesemuanya itu menjadikan yang ber-sangkutan suatu keu tuhan (keseluruhan) yang mempunyai 
ai tempat tersendiri (utuh, terpisah dari yang lain, mempunyai bentuk dan wujud)'

4. Mengakui adanya "rakyat" Rakyat ialah keseluruhan jumlah semua orang, warga dalam lingkungan daerah atau $\cdot$ negara tertentu, yang dalam segala sesuatu yang meliputi semua warga, dan untuk keperluan seIuruh warga, .termasuk hak dan kewajiban asasi kemanusiaan setiap warga, sebagai perseorangan dan sebagai penjelmaan hakikat manusia Hakikat rakyat adalah pilar negara dan yang berdaulat.

5. Mengakui adanya kualitas metafisis «tlaik" (trancendental good) yang hempa amI. Adil ialah dipenuhinya sebagai wajib segala sesuatu yang merupakan hak dalam hubu.ngan hidup kemanusiaan. Sebagai penjelmaan hakikat manusia .(wajib lebih diutaroakan daripada hak), pemenuhan hak sebagai kewajiban tersebut mencakup hubungan antara negara (pendukung wajib) dengan warga negaranya (disebut keadilan distributif), hubungan antara warga negara (pendukung wajib) dengan negara (disebut keadilan legal) dan hubungan di antar sesama warga negara (disebut keadilan Irumutatif). Keadilan mengandung inti adil yang pads hakikatnya adalah kerelaan (aspek jiwa) dan kesebandingan (aspek raga). Untuk memperjelas arti ontologis sila-sila Pancasila, periu diberi contohcontoh implementasinyamelalui pemahaman epistemologis, aksiologis yang direfleksikankedalam kehidupan antropologis.

c. Dasar-dasar Kefilsafatan Pancasilaa

Pancasna sebagai Sistem filsafat adalah berlandaskan pada hakekat kodrat manusia, walaupun semula tidak terpikirkan oleh tokoh-tokoh kenegaraan Indonesia 
tentang hakekat kodrat manusia, namun mena betul-betul perenungannya yang mendalam maka secara langstmg dijiwai oleh hakekat kodrat manusia dalam hidup bersama. Pancasila sebagai sistem. filsafat mempunyai ciri-ciri antara lain

Koherensi

Inklusif

Mendasar

Spekulatif

Sintesis

Komprehensif

Sistematis

d. Penalaran Filsafat

Penalaran filsafati merupakan bagian dan pemikirannya pada umumnya yang khusus berhubungan derikan penyimpulan. Penalaran filsafat haruslah bersifat koherensi dalam arti runtut dan tidak ada pertentangan di dalamnya sehingga hasil dan pemikiran ini yang disebut dengan filsafat, juga harus bersifat koheren dan harus mengikuti prinsip-prinsip pemikiran sebagai berikut:

Rasional

Analisis

Dealektika

Analitika Sintetik

Analisis Abstraksi

e. Ideologi dan Filsafat Pancasila 
Merupaka perangkat prinsip pengarahan yang dijadikan dasar serta memberikan arah dan tujuan untuk dicapai di dalam melangsungkan dan mengembangkan hidup dan kehidupannasional suatu bangsa dan negara. Adapun unsur- unsur ideologi antara lain:

Keyakinan

\section{Mitos}

Loyalitas

Pancasila sebagai ideologi negara secara spekulatif dirumuskan oleh tokohtakoh kenegaraan bangsa Indonesia pada tahun 1945 dalam sidang-sidang BPUPKI dan dilanjutkan dalam sidang-sidang PPKI yang menjadikannya sebagai dasar negara Indonesia.

\section{PENUTUP}

Dari apa yang telah dijelaskan di atas, Pancasila merupakan kesatuan yang tidak bisa dipisahkan, karena dalam masing-masing sila tidak bisa di tukar tempat atau dipindah. Secara ontologis pancasila sebagai filsafat dimaksudkan sebagai upaya untuk mengetahui hakikat dasar dari sils-sila pancasila. Pancasila terdiri atas lima asas yang berdiri sendirisendiri. Manusia merupakan pendukung pokok dari sila-sila pancasila. Maksudnya pada hakikatnya manusia memiliki hakikat mutlak.

Ontologi mempelajari ciri hakiki (pokok) dari keberadaan (Being) yang berbeda dari studi tentang hal-hal yang ada secara khusus. Ontologi merupakan cabang filsafat yang membicarakan tatanan (keteraturan) dan struktur kenyataan dalam arti yang luas. Kategori-kategori yang dipakai adalah: meng-ada atau menjadi, aktualltas atau 
potensionalitas, nyata atau nampak perubahan, eksistensi atau non-eksistensi, hakikat kemutlakan, yang terdalam.

Saran yang dapat dipetik dari materi ini adalah agar seluruh masyarakat mengetahui seberapa penting Pancasila dan dapat mengamalkan nilai-nilai sila dari pancasila dengan baik \& benar, serta tidak melecehkan arti penting pancasila.

\section{DAFTAR PUSTAKA}

Darmini Roza dan Laurensius Arliman S Peran Pemerintah Daerah Di Dalam Melindungi Hak Anak Di Indonesia, Masalah-Masalah Hukum, Volume 47, Nomor 1, 2018.

Laurensius Arliman S, Komnas HAM dan Perlindungan Anak Pelaku Tindak Pidana, Deepublish, Yogyakarta, 2015.

Laurensius Arliman S, Penguatan Perlindungan Anak Dari Tindakan Human Trafficking Di Daerah Perbatasan Indonesia, Jurnal Selat, Volume 4, Nomor 1, 2016.

Laurensius Arliman S, Problematika Dan Solusi Pemenuhan Perlindungan Hak Anak Sebagai Tersangka Tindak Pidana Di Satlantas Polresta Pariaman, Justicia Islamica, Volume 13, Nomor 2, 2016.

Laurensius Arliman S, Pelaksanaan Perlindungan Anak Yang Tereksploitasi Secara Ekonomi Oleh Pemerintah Kota Padang, Veritas et Justitia, Volume 2, Nomor 1, 2016.

Laurensius Arliman S, Kedudukan Ketetapan MPR Dalam Hierarki Peraturan PerundangUndangan Di Indonesia, Lex Jurnalica, Volume 13, Nomor 3, 2016. 
Laurensius Arliman S, Komnas Perempuan Sebagai State Auxialiary Bodies Dalam Penegakan Ham Perempuan Indonesia, Justicia Islamica, Volume 14, Nomor 2, 2017.

Laurensius Arliman S, Peranan Pers Untuk Mewujudkan Perlindungan Anak Berkelanjutan Di Indonesia, Jurnal Ilmu Hukum Tambun Bungai, Volume 2, Nomor 2, 2017.

Laurensius Arliman S, Mewujudkan Penegakan Hukum Yang Baik Untuk Mewujudkan Indonesia Sebagai Negara Hukum, Jurnal Hukum Doctrinal, Volume 2, Nomor 2, 2017.

Laurensius Arliman S, Participation Non-Governmental Organization In Protecting Child Rights In The Area Of Social Conflict, The 1st Ushuluddin and Islamic Thought International Conference (Usicon), Volume 1, 2017.

Laurensius Arliman S, Partisipasi Masyarakat Dalam Pembentukan PerundangUndangan Untuk Mewujudkan Negara Kesejahteraan Indonesia, Jurnal Politik Pemerintahan Dharma Praja, Volume 10, Nomor 1, 2017

Laurensius Arliman S, Peran Komisi Perlindungan Anak Indonesia Untuk Mewujudkan Perlindungan Anak, Jurnal Respublica Volume 17, Nomor 2, 2018.

Laurensius Arliman S, Menjerat Pelaku Penyuruh Pengrusakan Barang Milik Orang Lain Dengan Mempertimbangkan Asas Fungsi Sosial, Jurnal Gagasan Hukum, Volume 1, Nomor 1, 2019.

Laurensius Arliman S, Ilmu Perundang-Undangan Yang Baik Untuk Negara Indonesia, Deepublish, Yogyakarta, 2019. 
Laurensius Arliman S, Isdal Veri, Gustiwarni, Elfitrayenti, Ade Sakurawati, Yasri, Pengaruh Karakteristik Individu, Perlindungan Hak Perempuan Terhadap Kualitas Pelayanan Komnas Perempuan Dengan Kompetensi Sumber Daya Manusia Sebagai Variabel Mediasi, Jurnal Menara Ekonomi: Penelitian dan Kajian Ilmiah Bidang Ekonomi, Volume 6, Nomor 2, 2020.

Laurensius Arliman S, Pendidikan Kewarganegaraan, Deepublish, Yogyakarta, 2020.

Laurensius Arliman S, Makna Keuangan Negara Dalam Pasal Pasal 23 E Undang-Undang Dasar 1945, Jurnal Lex Librum, Volume 6, Nomor 2 Juni 2020,

Laurensius Arliman S, Kedudukan Lembaga Negara Independen Di Indonesia Untuk Mencapai Tujuan Negara Hukum, Kertha Semaya Journal Ilmu Hukum, Volume 8, Nomor 7, 2020.

Laurensius Arliman S, Pelaksanaan Assesment Oleh Polres Kepulauan Mentawai Sebagai Bentuk Pelaksanaan Rehabilitasi Bagi Pecandu Dan Korban Penyalahgunaan Narkotika, Jurnal Muhakkamah, Volume 5, Nomor 1, 2020.

Laurensius Arliman S, Aswandi Aswandi, Firgi Nurdiansyah, Laxmy Defilah, Nova Sari Yudistia, Ni Putu Eka, Viona Putri, Zakia Zakia, Ernita Arief, Prinsip, Mekanisme Dan Bentuk Pelayanan Informasi Kepada Publik Oleh Direktorat Jenderal Pajak, Volume 17, No Nomor, 2020.

Larensius Arliman S, Koordinasi PT. Pegadaian (Persero) Dengan Direktorat Reserse Narkoba Polda Sumbar Dalam Penimbangan Barang Bukti Penyalahgunaan Narkotika, UIR Law Review, Volume 4, Nomor 2, 2020 
Laurensius Arliman S, Tantangan Pendidikan Kewarganegaraan Pada Revolusi 4.0, Ensiklopedia Sosial Review, Volume 2, Nomor 3, 2020.

Muhammad Afif dan Laurensius Arliman S, Protection Of Children's Rights Of The Islamic And Constitutional Law Perspective Of The Republic Of Indonesia, Proceeding: Internasional Conference On Humanity, Law And Sharia (Ichlash), Volume 1, Nomor 2, 2020.

Otong Rosadi danLaurensius Arliman S, Urgensi Pengaturan Badan Pembinaan Idelogi Pancasila Berdasarkan Undang-Undang Sebagai State Auxiliary Bodies yang Merawat Pancasila dalam Perspektif Hak Asasi Manusia, Prosiding Konferensi Nasional Hak Asasi Manusia, Kebudayaan dan Tujuan Pembangunan Berkelanjutan Indonesia pada Masa Pandemi Covid-19: Tantangan untuk Keilmuan Hukum dan Sosial Volume 1, Universitas Pancasila, Jakarta, 2020.

file:///C:/Users/Acer/Downloads/31641-73968-1-SM.pdf

https://www.academia.edu/11505191/Filsafat_Pancasila_Ontologi_Epistimologi_dan_Aksiologi 